\title{
ВЕРХОВЕНСТВО ПРАВА В ПОСТМЕТАФІЗИЧНОМУ ДИСКУРСІ
}

\author{
БАУЛА Марина Валеріївна - студентка 2 курсу магістратури Навчально- \\ наукового юридичного інституту Київського міжнародного університету \\ УДК 304.12 \\ ORCID: $000000025662116 \mathrm{X}$ \\ DOI 10.32782/EP.2021.30
}

В статье исследуется вопрос о возможности конституирования постметафизического пространства, которое должно стать результатом преодоления метабизики в моменте собственного завершения. Также в рамках данного вопроса определяется необходимость переосмысления современного правового пространства с помощью конституирования постметабизического правового дискурса, необходимого для воплощения и утверждения верховенства права. Для переосмьлления современной правовой интеллектуальности важными являются филособбско-методологические и научнъие достижения $X X-X X I$ вв., в частности, изменения научной парадигмы исследований в области естествознания: термодинамики, квантовой механики Н. Бора и B. Гейзенберга, теорем К. Гёделя о неполноте аксиоматической системъ; а также лингвистический поворот, предпосълками которого также въгтупают фблособия языка 1 . Витгенштейна и фундаментальная онтология М. Хайдеггера. Благодаря лингвистическому повороту происходит становление язъка как того, ито опосредует постметабизический дискурс и требование постоянного пребъвания в нем человека, способного к правовому въгсказиванию, которое приводит к воплощению верховенства права.

Ключевъе слова: верховенство права, метафизика, постметафизика, постметафизический правовой дискурс, лингвистический поворот, поэтический язъик, правовой язълк, правовое творение, правовая истина.

\section{Постановка проблеми}

Сучасний світ $є$ завершенням історичного процесу метафізики, а тому постають питання: чи відбудеться становлення постметафізики як відмінного простору від метафізики в цілому, чи вдасться зберегти те, за допомогою чого стане можливим конституювання постметафізичного простору й, зокрема, постметафізичного правового дискурсу, необхідного для втілення і утвердження верховенства права. Починаючи з XX ст., дослідження цих питань $є$ важливим і фундаментальним для становлення нової інтелектуальності світу та переосмислення сучасного правового простору, який перебуває в нігілістичному спустошенні людського існування.

\section{Стан дослідження проблеми}

Дослідженню проблематики втілення верховенство права в правовому просторі присвячені наукові роботи як вітчизняних, так і зарубіжних учених: Р. Алексі, М. Антонова, В. В. Бібіхіна, В. С. Бігуна, Ч. Варги, Н. В. Варламової, С. П. Головатого, С. Касаткіна, А. Кауфмана, Г. Кельзена, С. І. Максимова, В. С. Нерсесянца, Н. І. Сатохіної, К. І. Скловського, М. М. Тарасова, О. В. Ткаченко, І. $\lambda$. Честнова та інших. Проте більшість глибинних питань цієї проблематики залишаються дискусійними або недослідженими в цілому. 


\section{Мета дослідження}

Мета цього дослідження полягає у розкритті передумов та процесу становлення філософсько-методологічних проблем втілення та утвердження верховенства права в межах постметафізичного правового дискурсу.

\section{Виклад основного матеріалу}

Е. Юнгер стверджував, що XXI ст. буде належати титанам, оскільки «вони в більшій мірі споріднені техніці, ніж мистецтву. Тому Ф. Гельдерлін радить поету заснути і шукати розради у Діоніса, поки панують «Залізні» - однак він знає, що боги повернуться» $[1$, с. 12,20$]$. «Титани відрізняються від богів, і ця відмінність стає очевидною в ïх ставленні до людини» [2, с. 105]: «титани не мають долі в тому сенсі, в якому володіє нею людина, вони іiі позбавлені ... Не мають долі і боги, i саме вони не мають ії там, де панує божественна необхідність, де, в сприйнятті людини, вона сама не протиставлена їм. Аюдина, якій протистоять титани, приречена на загибель» $[2$, с. 115]. У свою чергу, як вказував Ф. Юнгер, прихід Зевса все змінює: «Тепер людина повинна вибирати між титанами і богами, а це означає, що вона повинна очистити свою титанічну сутність до можливості перетворити ії в діонійську» $[2$, с. 118], яка робить можливим перехід до Аогосу, філософії і екстатичної сутності людини; такий перехід став можливий у філософії досократиків. Однак, якщо людина йде від богів і вони перестають брати участь в її долі - «повертається титанічне, яке починає вимагати влади. Там, де немає богів, там є титани ... Титани безсмертні, вони завжди тут і завжди прагнуть до того, щоб відновити своє минуле панування» [2, с. 123-124].

Титанічна сутність людини із аполлонівським розумінням Аогосу, зафіксовані Платоном в математичному мисленні, є основою метафізичних установок Р. Декарта і Г. Лейбніца, які у ХX ст. були розкритиковані і заперечені, оскільки виявилися нездатними пояснити ті радикальні зміни, які відбувалися в інтелектуальній сфері того часу - людське мислення починає повертатися до питання про буття сущого і питання діонійського Аогосу досократиків.
Осмислення світу стало неможливо починати з уже відомого і визначеного знання, яке побудоване на непорушній основі достовірної істини (fundamentum absolutum inconcussum veritas). Аюдське мислення починає розростатися і ширяти над безоднею буття сущого як потаємною областю, де людина лише й може отримати місце для свого перебування, де виникає почуття невідповідності та неадекватності метафізичних установок, й відповідно, постає необхідність постметафізичного переосмислення сучасної картини наукового світу. Початком такого переосмислення умовно визначають зміни наукової парадигми досліджень у сфері природознавства, завдяки яким буде створена нова сутність наукового мислення та нова змістовність інтелектуальності світу. Фундаментальність останнього прослідковується в таких наукових досягненнях сучасного природознавства, як термодинаміка, квантова механіка Н. Бора і В. Гейзенберга та теореми К. Гьоделя про неповноту аксіоматичної системи.

3 моменту відкриття термодинаміки наприкінці XIX ст. - початку XX ст. зникла основа для претензій на абсолютно достовірне знання майбутнього, яке було досягненням класичної новоєвропейської науки, яка зображувала картину світу, в якій будьяка подія однозначно визначається вихідними умовами, в якій всюди панує «залізна необхідність» і всезагальні безспірні закони - при достатній повноті знання можна передбачити будь-яку подію майбутнього, тобто вичислити, передбачити розрахувати абсолютно все. "Якщо наперед відомо все, що відбудеться, то будь-який супротив безглуздий і шкідливий, а його придушення - виправдано наукою». Aле із початком розвитку термодинаміки з'ясувалося, що закриті системи, які мають точний сценарій їх життя і наперед передбачувані в ній події, не здатні до розвитку і змін. Тому більшість об'єктів (зокрема, й право) відноситься до відкритих систем, оскільки «будь-яка спроба зрозуміти їх у рамках механістичної моделі завідомо приречена на провал» [3, с. 25-29].

Неможливість метафізичних установок Р. Декарта і Г. Аейбніца для подальшого наукового пізнання було продемонстровано 


\section{Філософія та психологія права}

й подіями, які пов'язані з початком квантової революції в фізиці, коли «краса і завершеність старої фізики здавалися зруйнованими» [4, с. 212]. Н. Бор і В. Гейзенберг, приступивши до створення квантової механіки, концептуально поривали зв'язки із положеннями математичної фізики XVII ст. За словами А. В. Ахутіна, епоха створення квантової теорії характеризується надзвичайно глибоким осмисленням сутності філософських проблем та продуктивністю філософських дискусій [4, с. 539], які поступово починають підтверджувати недостатність єдиного можливого критерію наукової істини. «Проникнення фізики в світ елементарних частинок поставило під сумнів можливість описати будь-яке явище ... одним єдино правильним способом» [5, с. 154].

Завдяки Н. Бору та В. Гейзенбергу філософія починає вкорінюватися в наукові дослідження природознавства та стає основою для формування В. Гейзенбергом принципу невизначеності, а Н. Бором - принципу додатковості, які стали одними із найважливіших методологічних принципів квантової механіки і науки XX ст. Ці принципи заперечують «онтологічний натуралізм» та виступають «епістемологічним обмеженням» у зв'язку із дослідженням фізичної реальності - досліджувана реальність створюється при вимірюванні і спостереженні, а не відкривається як щось вже наперед існуюче і задане. Таким чином, квантова фізика, на противагу метафізичним установкам Р. Декарта, концептуально інакше ставить питання про існування буття сущого.

Зміст принципу невизначеності В. Гейзенберга полягає в тому, що «будь-який опис (пояснення, інтерпретація) завжди неповний і вибірковий» [5, с. 154]: «кожний квантовий стан передбачає внутрішню невизначеність, яку неможливо подолати» [6, с. 7]. У свою чергу, Н. Бор, утверджуючи принцип додатковості в квантовій фізиці, вказував, що «ми маємо справу не з суперечливими, а доповнюючими один одного картинами явищ» $[6$, с. 7]. Н. Бор також особливо підкреслював свободу експериментатора [6, с. 8], зокрема, відповідно, до принципу додатковості спостерігач може вільно обирати в будь-який момент, навіть після фі- зичних взаємодій, подальші класичні умови експерименту, що тим самим підкреслювало повну «залежність результату дослідження від обраних засобів і методів» [5, с. 154].

Таким чином, особливий філософськонауковий зміст цих принципів демонструє відмову від позитивізму, метою якого 6 отримання об'єктивного знання. В. Гейзенберг стверджував, що в науці склалася така ситуація, яку Н. Бор описує так: «Кожен охоче приєднується до вимог прагматиків і позитивістів - ретельності і точності в деталях, максимальної ясності мови. Aле їх заборони повинні бути порушені» [4, с. 488]. Н. Бор вважав, що «у мови є ці риси своєрідного ширяння. Ми не знаємо в точності, що означає слово, і смисл сказаного нами залежить від зв'язку слів у реченні, від контексту, у якому проговорюється фраза, i супутніх обставин, які повністю неможливо навіть перечислити», так «складається ситуація в звичайній мові, тим більше - у мові поета. Й до певної міри теж відноситься до мови природознавства» [4, с. 408], а тому метою дослідження вже не є пізнання об'єкта як такого незалежно від експериментально поставленого питання - «у природознавстві предметом дослідження є вже не природа сама по собі, а природа, оскільки вона підлягає людському запитуванню» [4, с. 230]. На думку В. Гейзенберга, наукове пізнання втрачає форму завершених і остаточних систем саме в некласичній фізиці: «ми змушені користуватися різними способами опису, що виключають, але й також доповнюють один одного, адекватний же опис процесу досягається в кінцевому рахунку тільки грою різноманітних образів» [4, с. 158]. В. Гейзенберг також стверджував, що «щось подібне відбувається й у філософії права. Навіть якщо правова система вже існує, тим не менше, в кожній новій ситуації необхідно відшукувати нову правову норму» [4, с. 232].

Сьогодні важливим є й сам результат квантового експерименту, відповідно до якого «реальність не існує до тих пір, поки iï не виміряє сторонній спостерігач» [7]. Це положення підтверджує концепт квантового релятивізму, який «обумовлений визнанням неможливості існування єдиного способу опису дійсності» [5, с. 66] та конструкти- 
вістським підходом до наукового знання. Релятивізм обгрунтовує безліч рівноправних i рівноцінних точок зору, поглядів, гіпотез і теорій щодо одного і того ж об'єкта. 3 огляду на це, релятивізм являється констатацією принципового плюралізму і відмовою від метаконцепції в науці, а також неможливості єдиної універсальної наукової мови й принципової залежності наукового знання від мислення спостерігача.

Концепт релятивізму змінюе зміст правового пізнання як відносно онтологічного, так і епістемологічного елементу. По-перше, правова реальність не може існувати поза правом як самостійним способом мислення, правовою мовою, яка його опосередковує, по-друге, правова реальність не існує як даність із остаточними відповідями і завершеною апріорною системою правових смислів, оскільки конституювання правового простору завжди залежить від ефекту правового дискурсу як філософської рефлексії, тобто творення чи руйнування правових смислів та правової аргументації.

У зв'язку із концептом релятивізму важливе значення також мають теореми К. Гьоделя про неповноту аксіоматичної системи, які «спростовують можливість існування формалізованих несуперечливих і одночасно повних (завершених) систем». Відповідно до першої теореми К. Гьоделя: «Якщо система (множинність) несуперечлива, то вона неповна (незавершена); якщо ж вона повна (завершена), то вона суперечлива» [5, с. 69-70]. Відповідно до другої теореми К. Гьоделя: «Якщо формальна система несуперечлива, то неможливо довести ії несуперечливість засобами, формалізованими в цій системі. Усе це свідчать про те, що право не може бути закритою несуперечливою формальною системою» [5, с. 156-157] та в цілому стверджується «обмеженість класичної раціональності в аспекті неможливості формалізувати більш або менш складні системи (множинності або системи знаків) несуперечливим способом і обгрунтувати систему іiі власними методами. Тим самим встановлюється неповнота і суперечливість описів, пояснень і тим більш наперед даної реальності» [5, с. 287-288]. Іншими словами, теореми К. Гьоделя спростували твер- дження юридичної догматики про логічно завершену, замкнуту, самодостатню систему права.

Також за допомогою теорем К. Гьоделя були розкритиковані основні методологічні принципи аналітичної філософії, а саме прагнення знайти єдиний метод наукового дослідження, зокрема, було обгрунтовано неможливість створення метасистеми і метамови [5, с. 157, 226], які мали б стати основою для побудови універсальної науки. Представники логічного позитивізму як напряму аналітичної філософії, такі якГ. Фреге, Б. Рассел та $\mathcal{\lambda}$. Вітгенштейн були зосереджені на логічному аналізі мови, який був визначений основним методологічним завданням філософії. Філософія визначалася як аналітична діяльність розкриття логічної структури мови, яке повинно перетворити ії на точний інструмент для створення всезагальної єдиної науки («філософія не наука, а діяльність») [8, с. 270].

Відповідно, таке прагнення до універсальності було заперечено та призвело до початку лінгвістичного повороту ХX ст., який виступає як фундаментальна подія переходу від суто наукового бачення світу до його філософського осмислення, яке постійно витіснялося позитивізмом. Передумовою такого переходу виступають погляди «пізнього періоду» $\lambda$. Вітгенштейна, у яких філософія визначається як мовна гра, яка заснована на взаємозв'язку мови, мислення і світу. Мовна гра приводить філософію в плюралістичний світ значень, стаючи джерелом філософських проблем вживання мови як наслідку неможливості універсального рішення і значення, оскільки мова вбудована в наш життєвий та практичний досвід («головне джерело нашого нерозуміння в тому, що ми не споглядаємо вживання наших слів») [8, с. 273]. Таким чином, філософія мови $\mathcal{\lambda}$. Вітгенштейна заперечувала, що значення може бути стабільною і зафіксованою сутністю.

На думку I. $\curlywedge$. Честнова, лінгвістичний поворот став додатковим аргументом визнання конструктивістської епістемології як особливої характеристики концепту релятивізму. «Сучасна аналітична філософія не просто постулює опосередкованість науко- 


\section{Філософія та психологія права}

вого знання мовою, але й демонструє підпорядкованість мовним феноменам (включаючи не лише мову як структуру, але й їі використання в мовленні, дискурсивній практиці) всього процесу наукового пізнання» [5, с. 89]. «Таким чином, конструювання i відтворення правової реальності відбувається за допомогою знакових форм, найбільш важливою із яких являється мова» [5, с. 167].

Інакше кажучи, завдяки лінгвістичному повороту відбувається становлення мови як того, що опосередковує той чи інший дискурс як незвершеної розмови та опосередковує вимогу постійного перебування в цій розмові людини, оскільки лише вона здатна до того мовлення, яке приводить дискурс в актуальний і продуктивний стан. Саме людина необхідна для створення простору, який буде протилежним науково-технічному простору Р. Декарта і Г. Лейбніца як основі спустошення мови, вкоріненого в руйнації сутності людини. Протилежний простір становить художній (поетичний) простір як вільний і відкритий для людини, в основі творення якого лежить художне та поетичне слово, зокрема, поезія, яку Платон прогнав із свого вічного царства істинних ідей і благ через конфлікт із його філософією [9, с. 117]. Платон стверджував, що поезія ніколи не торкається істинності як ідеї, тому й заперечив авторитет поеми, оскільки та була близька софістиці через притаманну їй мінливість мови, авторитетом матеми [10, c. 15,20$]$.

Е. Юнгер вважав поворот філософії від наукового пізнання до мови великою подією, важливішою за всі відкриття фізики, оскільки людина вступає в ту область, у якій, нарешті, знову стає можливим їі союз 3 поетом [11, с. 143], який довгий час оберігав ті фундаментальні питання, які знову мають бути поставлені. За словами Е. Юнгера, мова є частиною власності, своєрідністю, Вітчизною людини, мова не лише подібна саду, вона також є однією із могутніших форм майна [11, с. 144]. «Існуе два різновиди історії, одна є історією світу речей, інша - історією світу мови; і ця друга здатна надати не лише найвище осягнення світу, але найбільш дієву силу», оскільки мова - це найближче та найрідніше буттю - мова 6
Творення - і в цьому полягає її неймовірна сила. «Мова ткнеться навколо тиші подібно до того, як оазис утворюється навколо джерела. Й існування поезії підтверджує, що вхід у позачасові сади вже вдавався. Цим живе час» $[11$, с. 145].

Так, В. В. Бібіхін стверджував, що лише «людина відповідає за те, щоб земля стала садом» [12, с. 350], тобто суть світу, яка не видима так само, як сад на порожньому пустирі, може знаходитися лише в мовному розкритті [12, с. 96]. Інакше кажучи, присутність світу в мові вимагає людини, яка може дати слово світу - «людина здійснюється, даючи слово світу» [12, с. 96], а тому «в невирішуваному рівнянні світу, мови і людини ми рухаємося по колу, вибратися із якого неможливо. Учасники рівняння взаємно здійснюють одне одного» [12, с. 100], заміна хоча 6 одного учасника рівняння призводить до знищення або радикальної зміни сутності інших учасників.

Важливо продовжувати осмислювати вимогу до людини - постійного перебування в розмові, яка висунута подією філософського повороту до мови. М. Гайдеггер вказував, що «людина повинна, перш ніж говорити, знову відкритися для вимоги буття з ризиком того, що їй мало або зрідка вдасться говорити у відповідь на цю вимогу. Аише так слову знову буде подаровано дорогоцінність його сутності, а людині - покров для перебування в істині буття» [13, с. 196]. «Метафізика відгороджується від тої простої й істотної обставини, що людина належить своїй сутності лише настільки, наскільки чує вимогу Буття. Аише від цієї вимоги у неї «є», нею знайдено те, в чому перебуває ії сутність. Аише завдяки цьому перебуванню у неї «є» її «мова» як покров, який оберігає властиву їй екстатичність. Стояння в просвіті буття є екзистенцією людини» [13, с. 198]. Екстатична сутність людини полягає в «екзистенції, тобто екстатичному виступі в істину буття» $[13$, c. 200]. Це стояння в істині буття є сутністю «буття-в-світі» [13, с. 213] як екстатичного відношення до світу, яке заперечує можливість визначення буття сущого в цілому. Ця обмеженість екстатичного існування визначається вимогою відкритості буття - просвіту буття, яке оберігається мовою людини, 
яка проявляє турботу, запитуючи кожного разу заново. Можливість звернення до просвіту буття є подією вступу в істину буття як процедури творення.

3 огляду на те, що «істина виявляється замкненою в межах мови, нічого, що перевищувало 6 мовний горизонт, немає» $[14$, с. 70], єдиним місцем процедури творення може бути лише художній (поетичний) простір, який складає самостійну сутність $\mathrm{i}$, як стверджує М. Гайдеггер, його місце є подібним до пустоти, яка лише повинна бути заповнена: «пустота подібна суті місця і тому є зовсім не відсутність, а творення» [13, с. 315]. Але це «місце не розташовується в заздалегідь заданому просторі типу фізично-технічного простору» [13, с. 316]. За словами Г.-Г. Гадамера, «художнє творення відкриває, розкриває свій власний світ» [9, с. 109], тому творення суті іншого місця, де перебуває людське мовлення, необхідне для того, щоб будувати і творити в просвіті буття, щоб оберігати його [15, с. 148] через здійснення істини в процедурі творення як мистецтві. «Усе мистецтво, яке надає перебувати істині сущого як такій, - у своїй сутності є поезією». Якщо визнати останнє, то тоді все мистецтво, в тому числі, й право, «потрібно зводити до поезії, тобто до мистецтва слова». «Де мова не перебуває в бутті ... там немає і відкритості сущого, а тому немає і відкритості не-сущого, пустоти» [16, с. 203-205], тобто лише відкритість уможливлює становлення художнього (поетичного) простору як того чи іншого дискурсу.

Тому поетична мова (поема) розглядається як спосіб філософського мислення, який здатний відкрити множинність буття сущого. Такий спосіб поетичного мислення протилежний математичному мисленню (матемі) як метафізичній мові, відповідно до якого все суще завжди вже наперед встановлене і засвідчене для повторення, можливість вийти за його межі і помислити заново відсутня. Іншими слова, стверджується, що саме поетичне мислення, яке завжди перебуває в людському мовленні та запитуванні, є постметафізичним мислення, за допомогою якого можна переосмислити сучасний правовий простір.
А. Бадью визначає, що умовою існування філософії є істинні процедури, «які відрізняються від накопичення знань своїм подієвим походженням. Поки відбувається лише те, що відповідає правилам деякого положення речей, можливо, звичайно ж, пізнання, правильні висловлювання, накопичення знань; неможлива тут істина». Для здійснення істиннісної процедури потрібно доповнення ще одною ситуацією, яке вводить в гру ще одне означаюче, яким й запускає родову процедуру. «Якщо початкову ситуацію не доповнює якась подія, немає жодної істини. У ній є лише те, що називається правдоподібністю». Філософія «не встановлює ніякої істини, а надає істинам місце» [10, с. 16-17].

О. В. Ткаченко вказує, що розуміння істини- $\alpha \lambda \dot{\eta} \theta \varepsilon \iota \alpha$, яке сформульовано М. Гайдеггером, і розуміння істини А. Бадью як «підвішеного до події нескінченного творення, незвідного до встановлених знань» має важливе значення для осмислення істини в правознавстві. Так, процедура істини$\alpha \lambda \eta \dot{\eta} \theta \varepsilon \iota \alpha$ як дейксис $\epsilon$ проблемо-породжуючим образом мислення, філософським дослідженням, «що не відсилає до якогось незмінного смислу, забезпечуючи його трансляцію, а навпаки, здатне порвати зі смислом, який штучно наділяється атрибутами позачасовості, здатне стати на одному рівні з вимогою творення нових смислів». Філософський дейксис постає усвідомленням того, що «в говорінні мови, яке завжди відбувається згідно з буттєвим посиланням долі, буття сущого по-різному становиться до нас, тобто по-різному до нас звертається» [14, с. 75-76]. «Буття повинно триматися невизначеним в своєму значенні, щоб приймати визначеність від того або іншого різноманітного сущого» [13, с. 173].

Г. Харт, як представник аналітичної $\phi \mathbf{i}-$ лософії права, перший здійснив інкорпорацію лінгвістичного повороту до правознавства $[17$, с. 34]. Але Г. Кельзен першим «вибудовує свою доктрину юридичної невизначеності (у тому числі стосовно судового рішення). При цьому щодо актів створення/застосування правових норм одночасно стверджується і теза визначеності, і теза невизначеності» [18, с. 270]. Г. Кельзен стверджував тезу правову невизначеність через 


\section{Філософія та психологія права}

неможливість заздалегідь передбачити всі можливі майбутні ситуації і рішення, через відсутність у праві правильної відповіді і правильного методу ії пошуку серед можливостей, закладених рамками норми, і через недостатність правового тлумачення для винесення судового рішення, яке передбачає застосування власного розсуду [18,с. 271-272], тобто творення права, результатом якого $\varepsilon$ індивідуальна норма як новий акт актуалізації правового дискурсу, яка не стає апріорною і незмінною, а завжди знаходиться під ризиком заперечення шляхом нової аргументативної діяльності, відмінного розуміння права. Так, на думкуМ. Антонова, саме завдяки Г. Кельзену були поставлені ключові методологічні питання, які знаменують собою своєрідний пункт неповернення юриспруденції до об'єктивності і нейтральності понять юридичної догми, а також є перспективними для обгрунтування ідеї верховенства права [19, с. 345, 352].

\section{Висновки}

Таким чином, якщо поза титанічно-технічним світом XXI ст., який вже приходить до свого логічного завершення, поза титанічною сутністю, втіленою в математичному мисленні як метафізичному мисленні в праві, - стане можливим конституювання постметафізичного світу, то лише людське мовлення буде здатне стати основною конституантою такого світу, а панування будь-якої іншої мови, зокрема, технічнонаукової, продовжить встановлювати метафізичну сутність світу, у якому все людське буде цілковито знищено. 3 огляду на це, процедура творення права (правової істини) у межах тези правової невизначеності як основна процедура постметафізичного правового мислення вимагає людини як екзистенції (екстатичної сутності людини) та іiі мови (правового висловлювання) для втілення верховенства права в постметафізичному дискурсі.

\section{Лiтература}

1. Юнгер Ә. Смена гештальта. Прогноз на XXI век / Пер. с нем. и послесл. А. Михайловского. Москва: Издание книж. магаз. «Циолковский», 2018. 80 с.
2. Юнгер Ф. Г. Греческие мифы / Пер с нем. А. П. Шурбелева. Санкт-Петербург: Владимир Даль, 2006. 398 с.

3. Скловский К. И. Собственность в гражданском праве. 5-е изд., перераб. Москва: Статут, 2010. 912 с.

4. Гейзенберг В. Избранные философские работы / Пер. с нем. А. В. Ахутин, B. В. Бибихин. Санкт-Петербург: Наука, 2006. $571 \mathrm{c}$.

5. Честнов И. А. Постклассическая теория права: монография. Санкт-Петербург: Алеф-Пресс, 2012. 650 с.

6. Ма К., Кэри Й., Цайлингер А. Мысленные эксперименты с отложенным выбором и их реализации / Пер. англ. А. В. Касимова. 2016. 46 с.

7. Эксперимент Уилера подтвердил принцип дополнительности для атомов. URL: https://nplus1.ru/news/2015/06/12/ atoms-backward-causation (дата звернення: 14.12.2020)

8. Хофмайстер Х. Что значит мыслить философски / Пер. с нем. Санкт-Петербург: Изд-во С.-Петерб. ун-та, 2006. 448 с.

9. Гадамер Г.-Г. Актуальность прекрасного / Пер. с нем. Москва: Искусство, 1991. $367 \mathrm{c}$.

10. Бадью А. Манифест философии / Сост. и пер. с франц. В. Е. Аапицкого. Санкт-Петербургб: Machina, 2003. 184 с.

11. Юнгер Ә. Уход в лес / Пер. с нем А. Климентова. 2014. 149 с.

12. Бибихин В. В. Язык философии. Москва: Языки славянской культуры, 2002. $416 \mathrm{c}$.

13. Хайдеггер М. Время и бытие: Статьи и выступления / пер. с нем. В. В. Бибихин. Москва: Республика, 1993. 447 с.

14. Ткаченко О. В. Істина як проблема структурування постметафізичного простору правознавства. Актуальні проблеми держави і права. 2014. Вип. 72. С. 65-79.

15. Хайдеггер М. Положение об основании. Статьи и фрагменты / Пер. с нем. Санкт-Петербург: Алетейя, 2000. 290 с.

16. Хайдеггер М. Исток художественного творения / пер. с нем. А. В. Михайлов. Москва: Академический Проект, 2008. 528 с.

17. Велика українська юридична енциклопедія: у 20 т. / Нац. акад. прав. наук 


\section{АНОТАЦІЯ}

у статті досліджується питання щодо можливості конституювання постметафізичного простору, який має стати результатом подолання метабізики у моменті власного завершення. Також у межах иъього питання визначається необхідність переосмислення сучасного правового простору за допомогою конституювання постметафізичного правового дискурсу, необхідного для втілення $і$ утвердження верховенства права. Для переосмислення сучасної правової інтелектуальності важливими $є$ філософсъко-методологічні та наукові досягнення XX-XXI cm., зокрема, зміни наукової парадигми досліджень у сфері природознавства: термодинаміки, квантової механіки Н. Бора i В. Гейзенберга, теорем К. Гьоделя про неповноту аксіоматичної системи; а також лінгвістичний поворот, передумовами якого також виступають філособбія мови $\mathcal{1}$. Вітгенштейна та фундаментальна онтологія М. Гайдеггера. Завдяки лінгвістичному повороту відбувається становлення мови як того, щзо опосередковує постметафізичний правовий дискурс та вимогу постійного перебування в нъому людини, здатної до того правового висловлювання, яке приводить до втілення верховенства права.

Ключові слова: верховенство права, метафізика, постметафізика, постметафізичний правовий дискурс, лінгвістичний поворот, поетична мова, правова мова, правове творення, правова істина.

України, Ін-т держави і права ім. В. М. Корецького НАН України, Нац. юрид. ун-т

\section{SUMMARY}

The article examines the question of possibility of constitution postmetaphysical field, which should be the result of overcoming metaphysics at the moment of its own completion. Also, within this question the necessity of rethinking of the modern legal field by means of the constitution of postmetaphysical legal discourse, which is necessary for realization and statement of the rule of law, is defined. Philosophical-methodological and scientific achievements of the XX-XXI centuries are important for rethinking modern legal intelligence, in particular, changes in the scientific paradigm of research in the field of science: thermodynamics, quantum mechanics of N. Bohr and W. Heisenberg, $K$. Gödel's incompleteness theorems; as well as the linguistic turn, the preconditions of its which are also L. Wittgenstein's philosophy of language and M. Heidegger's fundamental ontology. Due to the linguistic turn, the language is formed as the foundation of postmetaphysical legal discourse and requirement of permanent staying in its a human, who is capable of legal utterance, which leads to the realization of the rule of law.

Key words: rule of law, metaphysics, postmetaphysics, postmetaphysical discourse of law, linguistic turn, legal language, legal creation, legal truth.

ім. Ярослава Мудрого. Харків: Право. 2017. Т. 2: Філософія права. 1127 с.

18. Касаткін С. Позитивістська доктрина правової невизначеності (на прикладі вчень Г. Кельзена та Г. Харта). Філособія права $і$ загальна теорія права. 2014. № 1-2. С. 268-276.

19. Антонов М. Творчий шлях та правове вчення Ганса Кельзена. Філособія права $i$ загальна теорія права. 2013. № 1. С. 345-353. 